\title{
PROFIL JURUSAN PENDIDIKAN LUAR BIASA SEBAGAI ORGANISASI YANG BELAJAR
}

\author{
Indina Tarjiah
}

\begin{abstract}
The Departement of The Special Education is a unit in The School of Education, State University of Jakarta which has to be developed to meet its objectives and to serve the need of society. This study conducted a survey to know how this Department as an organization to develop itself by practicing the learning organization theory. The study found out that although The Department is making some changes to improve its quality, a further study is needed to get more data and to enrich the findings to ensure that this Department has been practiced learning organization principles.
\end{abstract}

Key words: learning organization, discipline, transformation, empowering

\section{PENDAHULUAN}

Konsep organisasi belajar atau learning organization menjadi populer ketika Peter Senge memunculkan gagasannya melalui teori Fiffth Dicipline. Menurut Senge (2000), ada lima disiplin atau lima pilar yang membuat suatu organisasi menjadi organisasi yang pembelajar, yaitu pertama, personal mastery artinya belajar untuk memperluas kapasitas personal dalam mencapai hasil kerja yang paling diinginkan dan menciptakan lingkungan organisasi yang menumbuhkan seluruh anggotanya untuk mengembangkan diri mereka menuju pencapaian sasaran dan makna bekerja sesuai dengan harapan yang mereka pilih. Kedua adalah mental models yaitu suatu proses bercermin, memperjelas, dan meningkatkan gambaran diri kita tentang dunia luar, dan melihat bagaimana mereka membentuk keputusan dan tindakan. Ketiga, shared vision adalah membangun rasa komitmen dalam suatu kelompok, dengan mengembangkan gambaran bersama tentang masa depan yang akan diciptakan, prinsip dan praktek yang menuntun cara kita mencapai tujuan masa depan tersebut. Keempat, team learning atau belajar beregu yaitu mentransformasikan pembicaraan dan keahlian berpikir (thinking skill), sehingga suatu kelompok dapat secara sah mengembangkan otak dan kemampuan yang lebih besar dibanding ketika masing-masing anggota kelompok bekerja sendiri. Kelima, system thinking adalah cara pandang, cara berbahasa untuk menggambarkan dan memahami kekuatan dan hubungan yang menentukan perilaku dari suatu sistem. Disipllin kelima ini membantu kita untuk melihat bagaimana mengubah sistem secara lebih efektif dan untuk mengambil tindakan yang lebih tepat sesuai dengan proses interaksi antara komponen suatu sistem dengan lingkungan sekitarnya.

Sementara itu, Marquardt (1996) mengemukakan bahwa dalam suatu organisasi yang belajar harus ada enam kunci keterampilan yang diperlukan untuk memaksimalkan setiap orang dalam organisasi tersebut. Keenam keterampilan tersebut mencakup pertama, system thinking adalah suatu konsep yang dijadikan sebagai kerangka untuk digunakan seseorang memahami secara utuh dan jelas suatu pola dan membantu seseorang melihat bagaimana perubahanperubahan dapat terjadi pada mereka yang berada dalam suatu lembaga atau organisasi. Kedua, mental models atau pola-pola mental adalah berkaitan dengan suatu asumsi yang mendalam yang berpengaruh pada bagaimana kita memahami dunia dan bagaimana kita mengambil bagian dari kegiatan-kegiatan yang ada dalam suatu lembaga atau organisasi di mana kita bekerja dan berada. ketiga, personal mastery atau penguasaan pribadi yaitu menunjukkan tingkat tinggi dari keahlian atau kecakapan seseorang pada suatu keterampilan bidang tertentu. Penguasaan pribadi memerlukan komitmen untuk belajar sepanjang hayat, sehingga dapat berkembang keahliannya, dan orang tersebut merasa aman, nyaman, dan senang untuk bekerja dan berkarya dalam lembaga atau organisasi tersebut. Keempat, team leraning atau belajar beregu fokus pada proses untuk bersatu secara kelompok dan mengembangkan kapasitas dari suatu regu untuk menciptakan belajar dan hasil-hasil yang sesuai dengan keinginan yang sesungguhnya dari setiap anggota dalam suatu lembaga atau organisasi sesuai dengan pencapaian dari organisasi tersebut. Kelima, shared vision melibatkan keterampilan menggali ber- 
bagai gambaran-gambaran di masa yang akan datang yang membantu mengembangkan komitmen dan masukan-masukan bagi pengembangan suatu lembaga atau organisasi. Keenam, dialog menunjukkan tingkat tinggi dari kemampuan mendengarkan, dan komunikasi di antara orang-orang yang berada dalam suatu organisasi yang memerlukan kebebasan dan kreativitas dalam mengeksplorasi isu-isu, kemampuan mendengar lebih dalam dari satu dengan yang lainnya. Dalam dialog ini melibatkan belajar bagaimana memahami pola-pola interaksi dari suatu regu atau tim dalam kegiatan belajar.

Berdasarkan pada uraian di atas, dalam makalah ini mencoba untuk menggambarkan penjelasan, baik secara teoritis dan praktis tentang suatu lembaga atau organisasi mengembangkan diri melalui belajar. Untuk melengkapi informasi tentang suatu lembaga atau organisasi yang telah belajar, penulis mencoba untuk menyebarkan angket tentang learning organization profile yang dibuat oleh Marquardt dan telah diterjemahkan kepada teman-teman dosen di jurusan Pendidikan Luar Biasa Fakultas Ilmu Pendidikan Universitas Negeri Jakarta.

\section{PEMBAHASAN}

\section{Analisis Instrumen/Angket Learning Organization}

Berdasarkan atas analisis angket yang telah saya disebarkan kepada teman-teman dosen di jurusan Pendidikan Luar Biasa Fakultas Ilmu Pendidikan Universitas Negeri Jakarta diperoleh informasi yang menggambarkan tentang profil jurusan Pendidikan Luar Biasa sebagai organisasi yang belajar.

Instrumen yang saya sebarkan adalah angket yang dikembangkan oleh Marquardt (1996) yang terdapat pada halaman akhir dari buku yang berjudul Building the Learning Organization. Dalam instrumen tersebut, ada lima aspek yang menjadi acuan suatu lembaga dikatakan sebagai organisasi yang belajar. Kelima aspek itu kemudian dijabarkan ke dalam beberapa item pertanyaan yang jawabannya berupa skala, sebagai berikut nilai 4 diberikan jika responden menjawab pertanyaan dengan kategori "sudah diterapkan secara sepenuhnya”. Nilai 3 diberikan jika responden menjawab beberapa pernyataan dengan kategori "sudah banyak diterapkan". Nilai 2 diberikan jika responden menjawab pertanyaan-pertanyaan tersebut dengan kategori "diterapkan dalam taraf yang cukup", Dan nilai 1 diberikan jika responden menjawab beberapa pertanyaan dengan kategori “belum banyak atau belum diterapkan".

Berikut ini adalah penjelasan dari kelima aspek yang menjadi dimensi pokok dari indikator suatu organisasi yang belajar, yaitu pertama, pertanyaan yang menyangkut dinamika belajar baik secara individu, tim (regu), dan organisasi. Dalam aspek ini dikembangkan lima pertanyaan sebagai indikator dari keterlibatan individu, tim (regu), dan organisasi untuk senantiasa belajar. Kedua, pertanyaan yang berkaitan dengan transformasi organisasi: melalui penyebarluasan visi serta membangun budaya, strategi, dan struktur yang mendukung ke arah lembaga sebagai suatu organisasi yang belajar. Ketiga, pertanyaanpertanyaan yang berkaitan dengan pemberdayaan, bagaimana jurusan PLB sebagai suatu organisasi memberdayakan setiap orang/anggota yang terlibat baik di dalam atau di luar, artinya bagaimana memberdayakan dosen-dosen, ketua jurusan, sekretaris jurusan, mahasiswa, cleaning service, masyarakat, orang tua, dan lain lain. Keempat, pertanyaan-pertanyaan yang berkaitan dengan pengelolaan pengetahuan yang meliputi penguasaan, penciptaan, penyimpanan, transfer, dan penggunaan dari pengetahuan dari setiap orang yang terlibat baik di dalam organisasi maupun di luar organisasi. Kelima, pertanyaan-pertanyaan yang berkaitan dengan penerapan teknologi artinya bagaimana sistem organisasi yang dibangun, bagaimana orang-orang di jurusan belajar dengan berbasis teknologi, lalu bagaimana dengan sistem pendukung elektronik untuk belajar.

\section{Dimensi Dinamika Belajar : Individual, Tim (Regu), dan Organisasi}

Ada lima pertanyaan yang diajukan untuk menggambarkan dinamika belajar di jurusan Pendidikan Luar Biasa sebagai organisasi yang belajar. Berdasarkan masukkan yang diperoleh maka dapat disimpulkan sebagai berikut:

Untuk pertanyaan nomor 1 yang berbunyi "kami diberi semangat dan diimbau agar mengelola diri sendiri untuk belajar dan berkembang" dari 10 responden/dosen yang diberikan angket semuanya menjawab dengan memberi nilai 4. Pertanyaan nomor 2 yang mengungkap tentang "setiap orang menggunakan keterampilan mendengar dan menggunakan umpan balik untuk menghindari salah tafsir mengenai informasi dan menghindari penolakan terhadap saluran komunikasi" menjawab 8 orang dengan skor 3 (sudah banyak diterapkan) dan 2 orang menjawab dengan skor 4 (sudah diterapkan sepenuhnya). Pertanyaan nomor 3 yang mengungkap "setiap orang dilatih dan dibina untuk belajar bagaimana harus 
belajar (learning how to learn)" dari 10 orang semuanya memberi jawaban dengan skor 4 artinya sudah diterapkan secara sepenuhnya learning how to learn. Pertanyaan nomor 4 yang mengungkap tim dan perorangan dalam belajar menggunakan action learning process dijawab dengan skor 3, artinya di jurusan Pendidikan Luar Biasa sudah diterapkan suatu proses belajar yang mengacu pada refleksi dari masalahmasalah yang dihadapi dalam pekerjaan dan menggunakan pengetahuan baru untuk memperbaiki pekerjaan selanjutnya. Pertanyaan nomor 5 yang mengungkap tentang setiap orang di jurusan dapat berpikir dan berbuat berdasarkan pemahamannya mengenai pendekatan sistem yang digunakan mendapat jawaban dengan skor 3, artinya menunjukkan bahwa jurusan pendidikan luar biasa sebagai suatu organisasi yang belajar dengan menggunakan pendekatan sistem sudah banyak diterapkan.

Dimensi Transformasi Organisasi : Visi, Budaya, Strategi, dan Struktur.

Dalam dimensi, ini ada lima pertanyaan juga yang diajukan pada sepuluh dosen di jurusan Pendidikan Luar Biasa. Berdasarkan jawaban yang telah diberikan maka dapat disimpulkan, sebagai berikut:

Dari pertanyaan nomor 1 sampai dengan nomor 5 yang menanyakan pertanyaan berturut-turut, sebagai berikut pimpinan tertinggi mendukung visi organisasi belajar, terdapat iklim yang mendukung dan menekankan pentingnya belajar, kami belajar baik dari kegagalan maupun dari kesuksesan, kesempatan belajar dipadukan ke dalam program dan kegiatan, organisasi dipandu untuk memaksimalkan komunikasi dan belajar di setiap lini. Maka jawaban yang diberikan pada pertanyaan tersebut semua menjawab dengan skor 4, artinya sudah diterapkan secara sepenuhnya hal-hal yang berhubungan dengan ide-ide di atas.

Dimensi Pemberdayaan : Pemimpin, Dosen, Mahasiswa, Masyarakat, dan Guru.

Ada lima pertanyaan juga yang diajukan pada 10 responden (dosen-dosen) yang mengungkap tentang pemberdayaan yang dilakukan di jurusan Pendidikan Luar Biasa sebagai organisasi yang belajar.

Dari pertanyaan nomor 1 sampai dengan pertanyaan nomor 5 yang berbunyi, sebagai berikut kami berupaya untuk membangun dan memberdayakan setiap orang untuk belajar dan berkarya; kekuasaan didesentralisasikan dan didelegasikan; manajer/ketua jurusan memegang peran dalam pelatihan, pembinaan, mentoring, dan memfasilitasi belajar; dan kami mencari informasi secara aktif kepada para pelanggan, dalam hal ini sekolah, guruguru, mahasiswa untuk mengetahui ide mereka perlunya belajar untuk meningkatkan mutu pelayanan dan mutu lulusan, kami berpartisipasi dalam belajar bersama dengan mahasiswa, guru-guru, siswa, masyarakat, institusi, dan asosiasi profesi. Dari kelima pertanyaan ini secara berturut-turut masing-masing dosen memberi jawaban dengan skor 4. Ini menunjukkan bahwa aspek yang berkaitan dengan pemberdayaan di lingkungan jurusan Pendidikan Luar biasa sudah diterapkan secara sepenuhnya.

Dimensi Pengelolaan Pengetahuan : Penguasaan, Penciptaan, Penyimpanan, Transfer, dan Penggunaan.

Dalam dimensi ini dikembangkan lima pertanyaan untuk mengungkap tentang pengelolaan pengetahuan yang dilakukan oleh organisasi dalam hal ini oleh jurusan Pendidikan Luar Biasa.

Pertanyaan nomor 1 yang bertanya tentang setiap orang memantau trend atau kecenderungan yang terjadi di luar organisasi atau jurusan dengan cara melihat apa yang dikerjakan oleh jurusan lain, seperti penetapan kendali mutu pekerjaan, menghadiri konferensi, melakukan dan menelaah hasil penelitian, seminar, dan lain-lain. Diperoleh skor jawaban empat dosen yang menjawab dengan skor 4 dan enam dosen yang menjawab dengan skor 3, artinya secara umum setiap dosen di jurusan Pendidikan Luar Biasa sudah melakukannya.

Pertanyaan nomor 2 yang mengungkap tentang setiap orang dilatih untuk memiliki keterampilan berpikir kreatif dan mencoba cara bekerja baru mendapat jawaban dengan skor 3. Ini artinya secara umum setiap orang di jurusan sudah diupayakan untuk menggunakan keterampilan berpikir kreatif dan mencoba hal-hal yang baru dalam memecahkan persoalan yang berkaitan dengan pengajaran dan pembelajaran.

Pertanyaan nomor 3 yang mengungkap tentang seringnya setiap dosen di jurusan Pendidikan luar Biasa dalam mengerjakan proyek penelitian, cara pengajaran, dan media pembelajaran dijawab dengan skor 3. Ini memberikan makna bahwa setiap orang di jurusan sudah melakukan atau pimpinan sudah menerapkan aspek ini dalam membelajarkan orangorang dalam jurusan.

Pertanyaan nomor 4 yang mengungkap tentang "kami memiliki sistem dan struktur yang dapat meyakinkan pengetahuan-pengetahuan penting yang diidentifikasi, disimpan, dan disediakan agar setiap orang yang akan menggunakannya dapat memperoleh dengan mudah mendapat jawaban dengan skor yang 
bervariasi antara 2 (dijawab oleh 5 orang) dan 3 (dijawab oleh 5 orang). Ini berarti secara umum sudah diterapkan dalam kadar yang cukup.

Pertanyaan nomor 5 yang mengungkap tentang kami terus menerus membangun strategi dan mekanisme untuk saling memberi dan berbagi pengetahuan dan pengalaman sebagai salah satu kegiatan belajar di jurusan Pendidikan Luar Biasa mendapat jawaban dengan skor 3, artinya kegiatan yang terus menerus untuk mengembangkan diri sudah banyak dilakukan diterapkan.

Penerapan Teknologi : Sistem Informasi, Belajar Berbasis Teknologi dan Sistem Pendukung Elektronik untuk Belajar.

Untuk mengungkap dimensi terakhir dari angket tentang organisasi yang belajar dikembangkan juga lima pertanyaan. Pertanyaan nomor 1 yang menanyakan tentang informasi berbasis komputer yang efektif dan efisien menolong organisasi (jurusan) untuk belajar dijawab oleh sepuluh responden dengan jawaban 4 ini menunjukkan bahwa jurusan sudah menerapkan sepenuhnya penggunaan komputer untuk belajar dan pembelajaran.

Pertanyaan nomor 2 yang mengungkap tentang setiap orang memiliki kesiapan membuka akses informasi yang sangat mudah (misalnya melalui jaringan lokal, nasional, internasional, dan internet) semua menjawab dengan skor 4. Ini menunjukkan bahwa jurusan telah melakukan dan memberi peluang pada setiap orang dengan cara memberikan sarana prasarana yang cukup memadai untuk diakses dari ruangan manapun. Mulai dari ruangan kajur, ruangan administrasi, ruang dosen, dan ruang lab disediakan sarana untuk dapat mengakses informasi tersebut.

Pertanyaan nomor 3 yang berkaitan dengan fasilitas organisasi atau jurusan untuk belajar seperti ruang pelatihan dan ruang konferensi dengan pendukung multimedia dijawab dengan skor nilai 2 ini mengandung arti bahwa masih diterapkan dalam taraf yang cukup, karena jurusan masih berkaitan dengan fakultas artinya untuk penggunaan yang lebih besar masih bergabung dengan fakultas, walaupun dalam kenyataannya fakultas sendiri belum memiliki ruangan yang cukup komprehensif untuk keperluan konferensi dengan penggunaan multimedia yang canggih.

Berdasarkan analisis dari tiap dimensi tersebut, dan setelah dilakukan penjumlahan perhitungan terhadap nilai skor yang dimunculkan dari tiap pertanyaan, maka secara keseluruhan jumlah skor tersebut dapat dilihat pada tabel skor keseluruhan, sebagai berikut.
Tabel 1. Keseluruhan Jumlah Skor Profil Jurusan Pendidikan Luar Biasa

\begin{tabular}{|c|l|c|}
\hline No & \multicolumn{1}{|c|}{ Dimensi } & Jumlah skor x \\
\hline 1 & $\begin{array}{l}\text { Dinamika belajar: individual, tim, } \\
\text { regu, dan organisasi }\end{array}$ & 170 \\
\hline 2. & $\begin{array}{l}\text { Transformasi organisasi: visi, budaya, } \\
\text { strategi, dan struktur }\end{array}$ & 200 \\
\hline 3. & $\begin{array}{l}\text { Pemberdayaan: Pimpinan jurusan, } \\
\text { dosen, mahasiswa, staff administrasi }\end{array}$ & 200 \\
\hline 4. & $\begin{array}{l}\text { Pengelolaan pengetahuan: } \\
\text { penguasaan, penciptaan, } \\
\text { penyimpanan, transfer dan } \\
\text { penggunaan }\end{array}$ & 150 \\
\hline 5 & $\begin{array}{l}\text { Penerapan teknologi: sistem informasi, } \\
\text { belajar berbasis teknologi, sistem } \\
\text { pendukung elektronik untuk belajar }\end{array}$ & 900 \\
\hline
\end{tabular}

Berdasarkan jumlah perhitungan skor yang berjumlah 900 maka dengan mengacu pada kriteria skor total yang dikemukakan oleh Marquardt (1996) pada halaman akhir dari bukunya, dapat dikatakan bahwa skor 900 dibagi dengan 10 (jumlah responden) $=90$, skor 90 berada dalam rentang 81-100 sehingga dapat dikatakan bahwa selamat, organisasi anda dalam hal ini jurusan Pendidikan Luar Biasa sangat siap untuk menjadi organisasi belajar.

\section{KESIMPULAN}

Dalam organisasi yang belajar orang-orang merasakan mereka melakukan sesuatu yang berarti baik bagi mereka secara personal maupun dalam konteks yang luas. Setiap individu diorganisasi berkembang, tumbuh dan memperbesar kapasitasnya untuk berkreasi.

Manusia akan lebih pintar bila bekerja bersama dalam organisasi, karena bekerja dengan banyak orang akan menghasilkan ide-ide dan kinerja yang lebih baik Visi organisasi haruslah muncul dari semua tingkatan dalam organisasi, sehingga mereka bisa memahami bagaimana tindakan mereka saling mempengaruhi satu sama lain.

Profil jurusan Pendidikan Luar Biasa sebagai suatu organisasi yang belajar tidak bisa hanya berdiri sendiri, akan tetapi perlu juga didukung oleh suprasistem yang ada. Dalam hal ini, Fakultas Ilmu Pendidikan yang juga harus menjadi bagian bahkan

Perspektif Ilmu Pendidikan - Vol. 19 Th. X April 2009 
pada tingkat universitas. Perlu adanya pengembangan wawasan pada semua unsur yang ada baik pada tataran jurusan, fakultas dan universitas mengenai profil suatu lembaga atau organisasi yang belajar. Dukungan sistem yang memadai pada setiap lini dan tingkatan akan mempermudah dan mempercepat orang-orang dalam suatu organisasi untuk belajar.

Analisis tentang profil jurusan PLB sebagai organisasi yang belajar ini masih perlu dikaji lebih detail dan waktu yang agak panjang untuk mendapatkan data dan informasi yang akurat. Hasil yang dimunculkan dalam analisis ini perlu juga dilengkapi dengan informasi dari responden yang berbeda seperti staf administrasi, mahasiswa, guru-guru dan sebagainya.

Dukungan sistem yang memadai pada setiap lini dan tingkatan akan mempermudah dan mempercepat orang-orang dalam suatu organisasi untuk belajar.

\section{DAFTAR PUSTAKA}

Marquardt, M.J. (1996) Building the laerning organization; A system approach to quantum improvement and global success. New York: McGraw-Hill.

Senge, P. (2000). A fifth discipline resource schools that learn. USA: Doubleday

\section{KETERANGAN PENULIS}

Indina Tarjiah, saat ini tercatat sebagai mahasiswa Pasca-sarjana Jurusan Teknologi Pendidikan Universitas Negeri Jakarta dan aktif sebagai dosen di Pendidikan Luar Biasa Fakultas Ilmu Pendidikan Universitas Negeri Jakarta. 